\title{
The influence of ruptured anterior cruciate ligament on the biomechanical weakening of knee joint and posterior cruciate ligament
}

\author{
A. Vulović1,2*, A. Vukićević1 ${ }^{1}$ G. Jovičić ${ }^{1}$, B. Ristić ${ }^{3}$, N. Filipović ${ }^{1,2}$ \\ ${ }^{1}$ Faculty of Engineering, University of Kragujevac, 6 Sestre Janjić Street, 34000 Kragujevac, \\ Serbia \\ e-mail: aleksandra.vulovic@kg.ac.rs \\ e-mail: arso_kg@yahoo.com \\ e-mail: gjovicic.kg.ac.rs@gmail.com \\ e-mail: fica@kg.ac.rs \\ ${ }^{2}$ Bioengineering Research and Development Center - BioIRC, 6 Prvoslava Stojanovića Street, \\ 34000 Kragujevac, Serbia \\ ${ }^{3}$ Faculty of Medical Sciences, University of Kragujevac, 69 Svetozara Markovića Street, 34000 \\ Kragujevac, Serbia \\ e-mail: branko.ristic@gmail.com \\ *corresponding author
}

\begin{abstract}
The aim of the present study was to estimate biomechanical weakening of human knee joint assuming the conditions that occur when a person is standing on one leg. A patient-specific three-dimensional model of the human knee joint was developed from medical scans, while loads and material characteristics were adopted from the literature. The considered model included the following materials: bones, menisci, articular cartilage and relevant ligaments (posterior cruciate ligament, lateral collateral ligament and medial collateral ligament). The finite element analysis was used for numerical calculation of the stress distribution and failure index of posterior cruciate ligament. The obtained failure index showed that there was no possibility for posterior cruciate ligament failure under the considered conditions. It was concluded that application of the finite element analysis can provide a better insight into the biomechanical condition of the injured knee joint.
\end{abstract}

Keywords: knee joint model, posterior cruciate ligament, finite element method, stress distribution, failure index

\section{Introduction}

Knee is considered one of the most complex and important joints in the human body, since it supports its weight. The knee consists of bones, menisci, cartilages, ligaments and muscles. Moreover, the knee is able to provide stability due to the ligaments as well as the menisci, the joint capsule and the musculature that surrounds the knee joint (Guess et al. 2014).

Ligaments are soft tissues with the main role to connect bones together. The mechanical function of ligaments is to provide normal joint motion and restrict abnormal joint movement. Each ligament provides stability and restrains knee motion in more than one degree of freedom, 
while the overall joint stability depends on the contributions of the individual ligaments and their interactions (Kiapour et al. 2013). The anterior cruciate ligament (ACL) stretches from the lateral condyle of femur to the anterior intercondylar area. It is often torn during knee bending or twisting. The posterior cruciate ligament (PCL) stretches from the posterior intercondylar area of the tibia to the medial condyle of the femur.

About $75 \%$ of ACL ruptures happen with minimal or no contact at the time of injury (Boden et al. 2000). Remaining ACL ruptures involve some outside force. ACL injuries most commonly occur during a change in velocity of motion that is combined with a change of direction (Silvers and Mandelbaum 2011). An injury to PCL is very uncommon, but it can occur under direct trauma to the ligament.

The finite element (FE) analysis is very popular in the field of biomechanics. This type of analysis can provide information that are not always possible to obtain from experiments. Many authors have been analyzing anterior cruciate ligament problems (Filipović et al. 2013; Song et al. 2004; Limbert et al. 2004). The accuracy of FE analysis depends on the accurate input information. This is a problem because mechanical behavior of the knee joint is not completely known. This is especially true for parts of the knee joint such as ligaments and menisci.

\section{Materials and methods}

\section{$2.13 D$ geometry knee model}

The right knee from a 40 year-old female was scanned using MRI. The knee was scanned while the patient's leg was in full extension. Resolution of scans was 320 x 320 pixels and slice increment was $0.589 \mathrm{~mm}$. The process of segmentation and generation of the knee model from scans was performed in Mimics 10.01 (Materialise, Leuven, Belgium). The second step was refinement of created elements and their assembly which was done in Geomagic Studio 2013 (Raindrop Geomagic Inc, Research Triangle Park, NC, USA).

The developed knee model is shown in Figure 1.
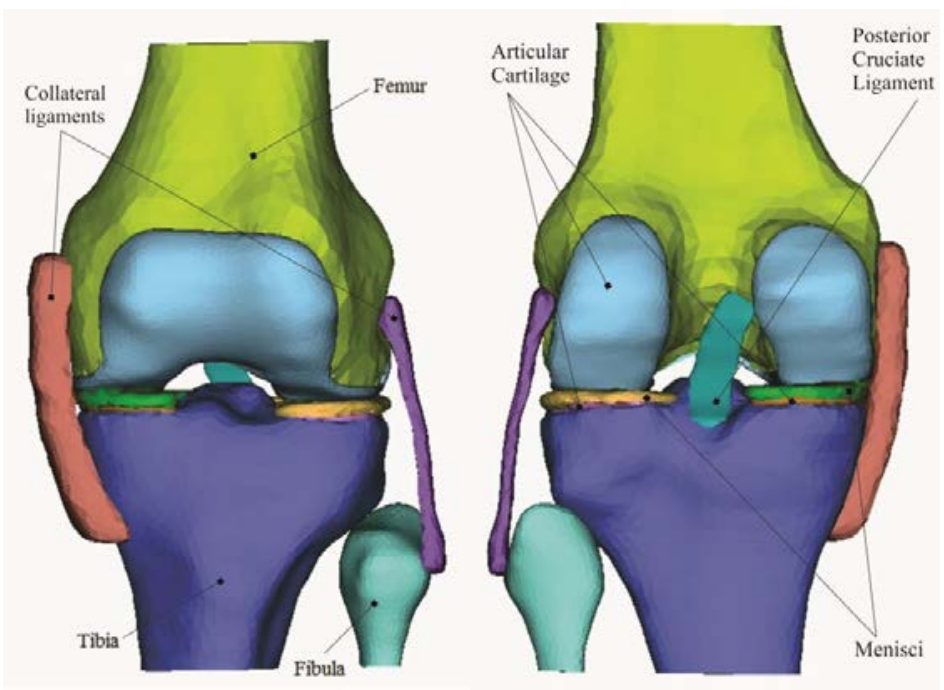

Fig. 1. 3D knee joint model. (a) Anterior view; (b) Posterior view 
Model consists of femur (cortical and cancellous), tibia (cortical and cancellous), fibula, articular cartilage (femoral and tibial), menisci (lateral and medial) and ligaments (posterior cruciate ligament, medial collateral ligament and lateral collateral ligament). Since we considered the patient with ruptured ACL, we did not model that part of the knee.

\subsection{D geometry knee model}

Material properties used for simulation were gathered from the literature. Properties found in the literature were mostly obtained from different experiments. Those values varied from paper to paper due to different conditions in which experiments were performed. Also, those material properties depended on many factors such as age, race, measurer, experimental conditions etc. Table 1 lists all the materials used for calculation, as well as their properties (Young's modulus, Poisson's ration). All the materials used for calculation are considered to be linear elastic, homogenous and isotropic.

\begin{tabular}{|l|l|l|}
\hline Material & Young’s modulus [MPa] (Ref.) & Poisson’s ratio (Ref.) \\
\hline Femur - cortical & 14317 (Soni et al. 2007) & 0,315 (Soni et al. 2007) \\
\hline Femur - spongy & 295 (Soni et al. 2007) & 0,315 (Soni et al. 2007) \\
\hline Tibia - cortical & 20033 (Soni et al. 2007) & 0,315 (Soni et al. 2007) \\
\hline Tibia - spongy & 295 (Soni et al. 2007) & 0,315 (Soni et al. 2007) \\
\hline Fibula & 17000 (Tseng et al. 2014) & 0,3 (Tseng et al. 2014) \\
\hline Articular cartilage & 12 (Hopkins et al. 2010) & 0,45 (Hopkins et al. \\
\hline Menisci & 80 (Hopkins et al. 2010) & 0,3 (Hopkins et al. 2010) \\
\hline Ligaments & 345 (Soni et al. 2007) & 0,22 (Soni et al. 2007) \\
\hline
\end{tabular}

Table 1. Material properties of knee joint elements

\subsection{Constraints}

The considered constraints correspond to physiological conditions that occur when a person is standing on the right leg while it is fully extended (Figure 2). Nodes on the lower surface of the tibia and fibula were fixed in all three directions. All nodes, except those that were fixed, were allowed to move along $\mathrm{x}, \mathrm{y}$ and $\mathrm{z}$ axis.

\subsection{Load}

Vertical compression force was applied to the upper surface of the femur, as shown in Figure 2. The applied force of 1000 [N] was calculated based on the information of the gait cycle in full extension (Kutzner et al. 2010). 


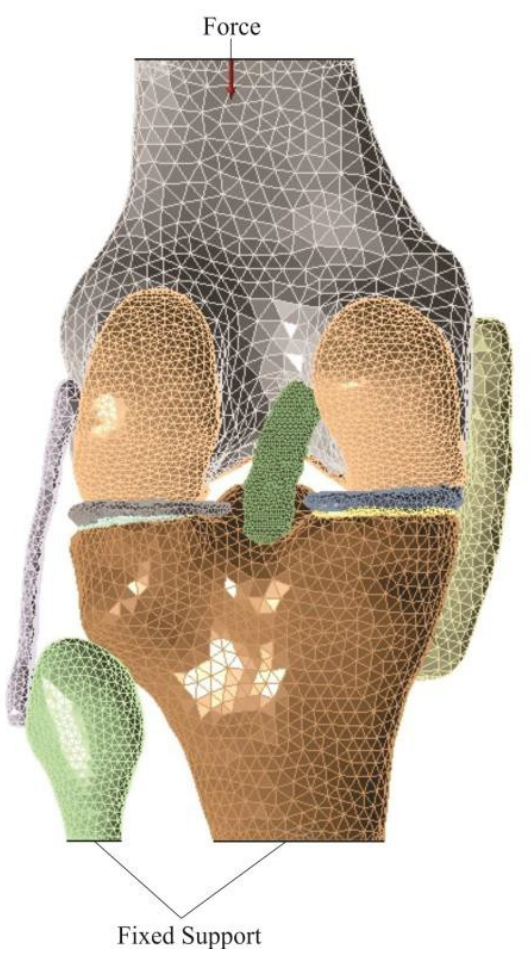

Fig. 2. Constraints and load for knee model

The contacts between various parts of the model were modeled as bonded contacts. They were detected automatically by the software, assuming that the contact should be defined on the place where faces of the various materials overlap (Figure 3).

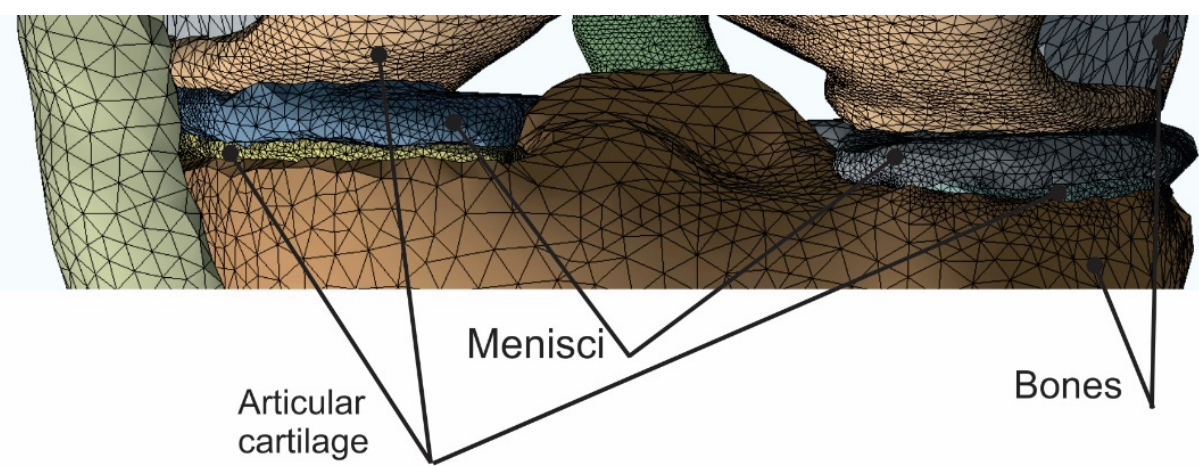

Fig. 3. Magnified contact area between bones, cartilages and menisci

The 3D finite element analysis of the knee joint during standing on one leg was conducted using software ANSYS 14.5.7 (SASI, Canonsburg, PA, United States of America). 


\section{Results}

Results from this type of simulation depend on the quality of the created 3D model and on mathematical descriptions of the behavior of the biological tissues involved.

Figure 4 shows stress distribution for the knee joint in the case of previously described situation (person is standing on one leg and has ruptured ACL). The stress values in the knee joint bones (femur, tibia and fibula) are in range from $45 \mathrm{~Pa}$ to $7 \mathrm{MPa}$.
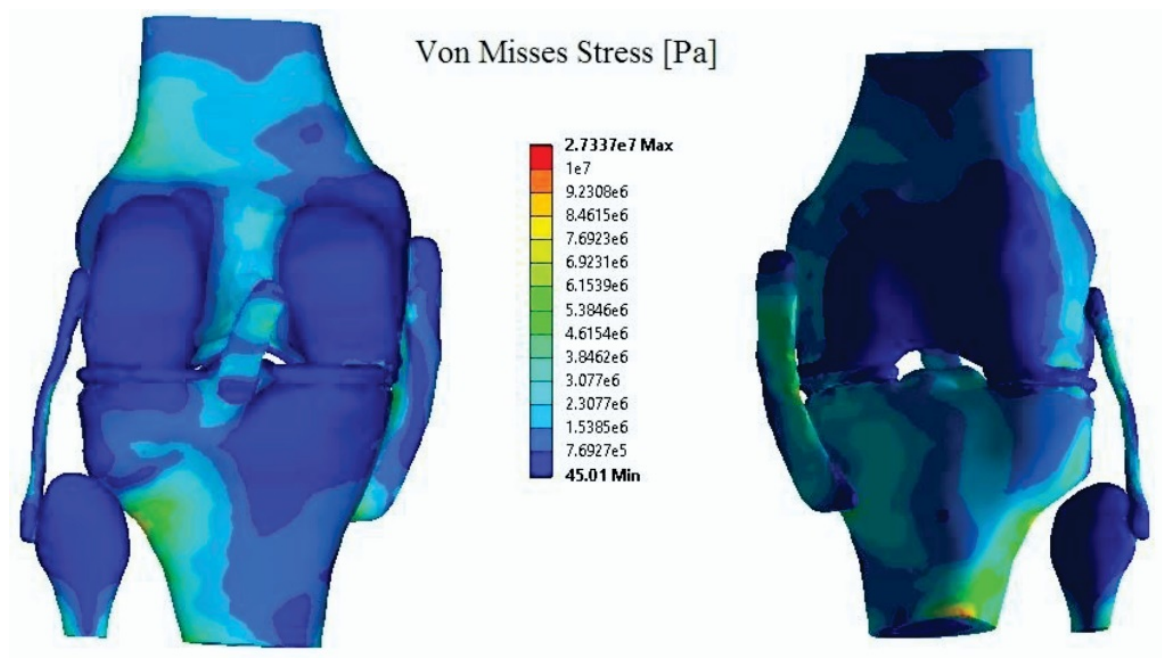

Fig. 4. Stress distribution on the knee joint - posterior and anterior view

Similar stress range is noticeable on the lateral and medial collateral ligament. For collateral ligaments, stresses are in range from $45 \mathrm{~Pa}$ to $6.5 \mathrm{MPa}$. As it can be seen in Figure 4, stress range for posterior cruciate ligament is comparable to the range of the collateral ligaments.

The regions with the highest Von Mises stress are indicated by the arrows in Figure 5.

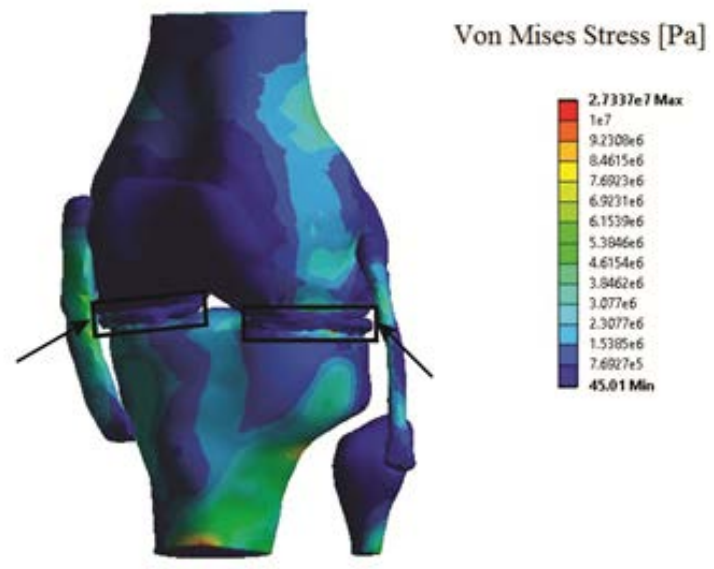

Fig. 5. Stress distribution on the knee joint - side view 
The highest stress is on the medial and lateral menisci. Maximum stress value for this boundary conditions and load was calculated to be about $10 \mathrm{MPa}$. Based on the role that menisci have in the knee joint, this distribution was expected.

Besides Von Misses stress for the knee joint, we were interested to calculate Failure Index (FI) of PCL when ACL is ruptured and a person is standing on one leg. For calculation of FI we used the previously calculated Von Misses stress for PCL and the material properties of PCL that we obtained from literature (Amis et al. 2003). Results for FI of PCL are shown in Figure 6 and the region with the highest FI is indicated by the arrow.
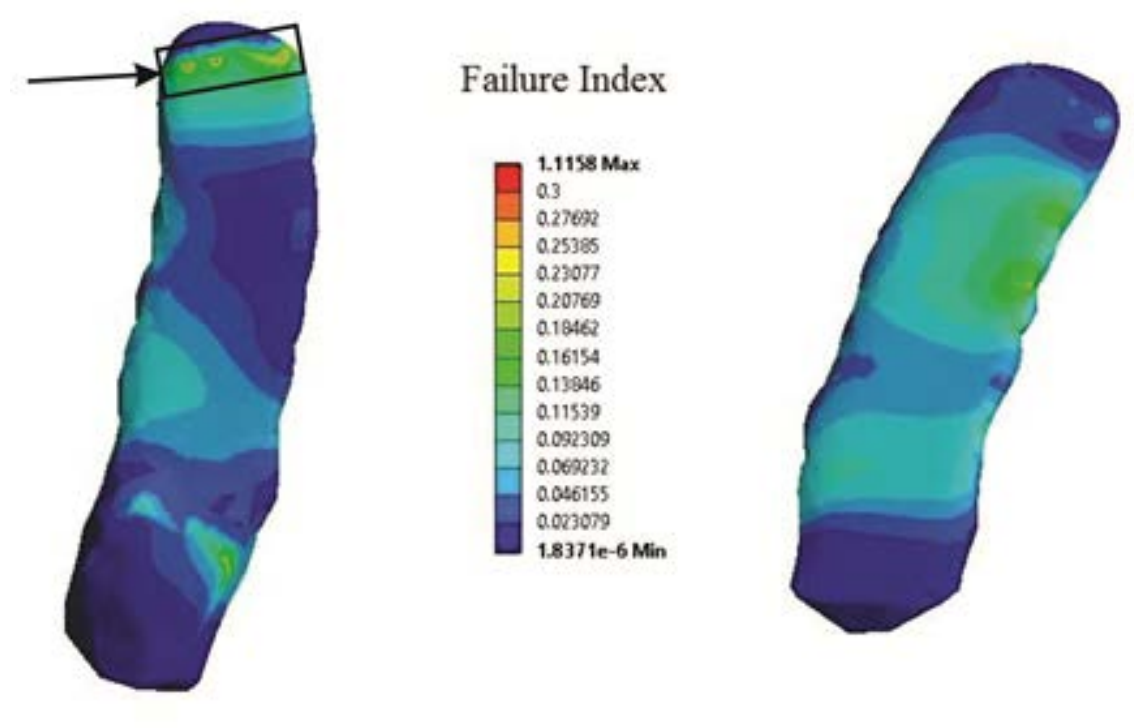

Fig. 6. Failure index for PCL

The maximum failure index is calculated to be 0.3 and it is in the area of connection between the posterior cruciate ligament and the femur. This means that in the described situation (ACL is ruptured and a person in standing on one leg), the posterior cruciate ligament that is healthy will not rupture.

\section{Conclusions}

Although we are able to create different situations with the finite element model, we are still missing some fundamental understanding of knee biomechanics, such as injuries and disease and their progression. The model presented in this paper includes all the relevant articular cartilages, menisci and ligaments.

The goal of this study was to determine if there was a possibility that posterior cruciate ligament would rupture under the previously described conditions. This simulation shows that in case previously described situation happened, posterior cruciate ligament would not be threatened.

There are some limitations concerning the presented model. The effect of the muscles was not considered. Also, the material properties were taken from the literature and they were not the same as the material properties of the person whose scans we used for our analysis. The 
analysis was conducted for the knee joint in full extension and the next step would be to analyze a full gait cycle.

This leaves room for future studies using a more precise model of the human knee joint with better material properties such as nonlinearity, inhomogeneity and anisotropy.

Извод

\title{
Утицај руптуре предњег укрштеног лигамента на биомеханичко слабљење зглоба колена и задњи укрштени лигамент
}

\author{
А. Вуловић ${ }^{1,2 *}$, А. Вукићевић ${ }^{1}$, Г. Јовичић ${ }^{1}$, Б. Ристић ${ }^{3}$, Н. Филиповић ${ }^{1,2}$ \\ 1 Факултет инжењерских наука, Универзитет у Крагујевцу, Сестре Јањић 6, 34000 \\ Крагујевац, Србија \\ имејл: aleksandra.vulovic@kg.ac.rs \\ имејл: arso_kg@yahoo.com \\ имејл: gjovicic.kg.ac.rs@gmail.com \\ имејл: fica@kg.ac.rs \\ 2 Истраживачко-развојни центар за биоинжењеринг БиоИРЦ, Првослава Стојановића 6, \\ 34000 Крагујевац, Србија \\ 3 Факултет медицинских наука, Универзитет у Крагујевцу, Светозара Марковића 69, \\ 34000 Крагујевац, Србија \\ имејл: branko.ristic@gmail.com \\ *ллавни аутор
}

\section{Резиме}

Циљ овог рада јесте процена биомеханичког слабљења зглоба колена, уз претпоставку услова који се јављају када особа стоји на једној нози. Тродимензионални модел зглоба колена креиран је на основу медицинских снимака, док су оптерећења и материјалне карактеристике усвојени из литературе. Разматрани модел садржи следеће материјале: кости, менискус, зглобну хрскавицу и битне лигаменте (задњи укрштени лигамент, латерални колатерални лигаменат и медијални колатерални лигамент). Метода коначних елемената коришћена је за израчунавање расподеле напона у зглобу колена и индекса отказа задњег укрштеног лигамента. Израчунати индекс отказа показао је да не постоји могућност за пуцање задњег укрштеног лигамента при посматраним условима. Закључено је да примена методе коначних елемената омогућава бољи увид у биомеханичко стање повређеног зглоба колена.

Кључне речи: модел зглоба колена, задњи укрштени лигамент, метода коначних елемената, расподела напона, индекс отказа 


\section{References}

Amis AA, Bull AMJ, Gupte CM, Hijazi I, Race A, Robinson JR (2003). Knee Surg. Sports Traumatol. Arthrosc, 11, 271-281.

Boden BP, Dean GS, Feagin Jr JA (2000). Mechanisms of anterior cruciate ligament injury.

Orthopedics, 6, 573-578.

Filipović N, Isailović V, Nikolić D, Peulić A, Mijailović N, Petrović S, Ćuković S, Vulović R, Matić A, Zdravković N, Devedžić G, Ristić B (2013). Biomechanical Modeling of Knee for Specific Patients with Chronic Anterior Cruciate Ligament Injury. ComSIS, 10, 525545.

Guess TM, Razu S, Jahandar H, Stylianou A (2015). Predicted loading on the menisci during gait: The effect of horn laxity. Journal of Biomechanics, 48, 1490-1498.

Hopkins AR, New AM, Rodriguez-y-Baena F, Taylor M (2010). Finite element analysis of unicompartmental knee arthroplasty. Medical Engineering \& Physics, 32, 14-21.

Kiapour AM, Kaul V, Kiapour A, Quatman CE, Wordeman SC, Hewett TE, Demetropoulos CK, Goel VK (2014). The Effect of Ligament Modeling Technique on Knee Joint Kinematics: A Finite Element Study. Appl Math, 4, 91-97.

Kutzner I, Heinlein B, Graichen F, Bender A, Rohlmann A, Halder A, Beier A, Bergmann G (2010). Loading of the knee joint during activities of daily living measured in vivo in five subjects. Journal of Biomechanics, 43, 2164-2173.

Limbert G, Taylor M, Middleton J (2004). Three-dimensional finite element modelling of the human ACL: simulation of passive knee flexion with a stressed and stress-free ACL. Journal of Biomechanics, 37, 1723-1731.

Silvers HJ, Mandelbaum BR (2011). ACL Injury Prevention in the Athlete. Sports Orthopaedics and Traumatology, 27, 18-26.

Song Y, Debski RE, Musahl V, Thomas M, Woo SL-Y (2004). A three-dimensional finite element model of the human anterior cruciate ligament: a computational analysis with experimental validation. Journal of Biomechanics, 37, 383-390

Soni A, Chawla A, Mukherjee S (2007). Effect of muscle contraction on knee loading for a standing pedestrian in lateral impacts. In Proceedings of 20th ESV conference, Paper No. 467.

Tseng J-G, Huang BW, Liang S-H, Yen KT, Tsai YC (2014). Normal Mode Analysis of a Human Fibula. Life Sci J, 11, 711-718. 